\title{
Pertumbuhan dan hasil genotipe kedelai (Glycine max (L.) Merril) pada tiga tingkat cekaman kekeringan
}

Growth and yield of soybean (Glycine max (L.) Merril) genotypes at three levels of drought stress

\author{
Nia Romania Patriyawaty ${ }^{1 *}$, Gatut. W. Anggara ${ }^{2)}$ \\ ${ }^{1}$ Puslitbang Tanaman Pangan, Jl. Merdeka No. 147, Bogor, Indonesia \\ ${ }^{2}$ Balai Penelitian Tanaman Aneka Kacang dan Umbi, Jl. Raya Kendalpayak No. 66, Malang, Indonesia \\ *E-mail korespondensi: niarpatria@gmail.com
}

Informasi artikel: Dikirim: 09/05/2020 ditinjau: $11 / 05 / 2020$ disetujui: 26/07/2020

cc) (7)

Copyright (c) 2020 Nia R. Patriyawaty, Gatut. W. Anggara
ABSTRACT: The purpose of this study was to evaluate the growth and yield of five soybean genotypes (G) against three levels of drought (D) tested in a greenhouse. The study was arranged in factorial RAK 3 times. The first factor is soybean genotype with 5 levels, namely: G162 (G1), A6 (G2), Black-5 (G3), Detam-1 (G4) and Ring-1 (G5), and the second factor is three levels of drought stress with 3 levels namely: 100\% (D1), 80\% (D2) and 60\% (D3) of field capacity. Data analysis for growth, flowering, and yield parameters was carried out using ANOVA followed by Tukey's further tests using Minitab software 17. The experimental results showed that drought stress had a significant effect ( $P$ $<0.001)$ on soybean genotype growth. The response of soybean genotypes to drought stress also showed a significant difference $(P<0.05)$. Drought stress significantly reduced the soybean genotype yield by $15.7 \%$ to $23.4 \%$. The percentage reduction in genotype $G 1$ yield (0.52\%) is smaller than other genotypes. This indicates that the genotype is drought-tolerant. Evaluation of soybean genotype growth and yield has the potential to be used as a selection tool in a drought-tolerant soybean breeding program.

Keywords: Drought stress, Glycine max (L.) Merril, growth and yield

ABSTRAK: Tujuan penelitian ini adalah untuk mengevaluasi pertumbuhan dan hasil lima genotipe kedelai (G) terhadap tiga tingkat kekeringan (D) yang diuji dalam rumah kaca. Penelitian disusun dalam RAK faktorial diulang tiga kali. Faktor pertama adalah genotipe kedelai dengan 5 taraf yaitu: G162 (G1), A6 (G2), Hitam-5 (G3), Detam-1 (G4) dan Dering-1 (G5), dan faktor kedua adalah tiga tingkat cekaman kekeringan dengan 3 taraf yaitu: 100\% (D1), 80\% (D2) dan 60\% (D3) dari kapasitas lapang. Analisis data untuk parameter pertumbuhan, pembungaan dan hasil dilakukan dengan menggunakan ANOVA yang dilanjutkan dengan uji lanjut Tukey dengan menggunakan perangkat lunak Minitab 17. Hasil percobaan menunjukkan cekaman kekeringan berpengaruh nyata $(P<0.001)$ terhadap pertumbuhan genotipe kedelai. Respon genotipe kedelai terhadap cekaman kekeringan juga menunjukkan perbedaan yang signifikan $(P<0.05)$. Cekaman kekeringan secara signifikan menurunkan hasil genotipe kedelai sebesar $15.7 \%$ hingga $23.4 \%$. Persentase penurunan hasil genotipe $\mathrm{G} 1(0.52 \%)$ lebih kecil dibanding genotipe lainnya. Hal ini mengindikasikan genotipe tersebut sebagai genotipe toleran kekeringan. Evaluasi pada pertumbuhan dan hasil genotipe kedelai berpotensi untuk dijadikan alat seleksi dalam program pemuliaan kedelai toleran kekeringan.

Kata kunci: Cekaman kekeringan, Glycine max (L.) Merril, pertumbuhan dan hasil

Sitasi: Patriyawaty, N. R., \& Anggara, G. W. (2020). Pertumbuhan dan hasil genotipe kedelai (Glycine max (L.) Merril) pada tiga tingkat cekaman kekeringan . AGROMIX, 11(2), 151-165. https://doi.org/2010.35891/agx.v11i2.2024

\section{PENDAHULUAN}

Perubahan iklim berdampak sangat serius produksi biji-bijian yang diprediksi akan menurun hingga 17\% (FAO, 2016). Penelitian terhadap produksi pertanian, termasuk tentang adaptasi tanaman dalam menghadapi 
perubahan iklim saat ini marak dilakukan di beberapa negara, terutama dalam mencari varietas tanaman yang tahan terhadap cekaman kekeringan, cekaman terhadap salinitas dan sebagainya. Adaptasi sistem pertanian sangat dibutuhkan untuk memecahkan masalah kekurangan pangan dunia terkait dengan perubahan iklim yang sudah terjadi.

Cekaman kekeringan secara signifikan berdampak terhadap penurunan produktivitas pertanian di seluruh dunia, termasuk produksi biji kedelai yang diuji di Florence, SC, USA (Buezo dkk., 2019). Di Indonesia, kedelai sering ditanam sebagai tanaman sela setelah padi yang mana banyak dibudidayakan pada saat kemarau. Produksi kedelai pada musim tersebut terkendala dengan ketersediaan air yang terbatas sehingga pada sebagian atau seluruh fase pertumbuhan tanaman tercekam kekeringan. Seiring dengan peningkatan suhu udara yang disebabkan oleh pemanasan global, hal ini juga berdampak buruk terhadap pertumbuhan kedelai dan selanjutnya berdampak pada hasil biji (Daryanto dkk., 2015). Salah satu upaya memperbaiki pelandaian produktivitas kedelai yang disebabkan oleh masalah kekeringan adalah melalui penanaman varietas toleran kekeringan. Dengan demikian perakitan varietas kedelai toleran kekeringan sangat berperan untuk meningkatkan produktivitas kedelai secara nasional. Pemerintah melalui
Badan Penelitian dan Pengembangan Pertanian telah merilis varietas kedelai berbiji kuning yang tahan kekeringan (varietas dering), namun khusus untuk varietas berbiji hitam masih terbatas (Balitbangtan, 2016).

Secara umum cekaman kekeringan mempengaruhi pertumbuhan fase vegetative dan generative tanaman yang akhirnya berdampak pada penurunan hasil panen. Namun, fase reproduktif merupakan fase yang sangat sensitive terhadap cekaman kekeringan karena secara langsung berdampak terhadap proses pembungaan dan pengisian polong (Hatfield dkk., 2011). Ghassemi-Golezani, dkk., (2010) menyatakan bahwa penurunan jumlah bunga dan jumlah polong isi merupakan akibat yang terjadi dari cekaman kekeringan pada fase reproduktif. Mekanismenya, distribusi karbohidrat dari daun ke polong terhambat sehingga terjadi penurunan jumlah dan ukuran biji (Alqudah dkk., 2010).

Hasil penelitian sebelumnya menyatakan bahwa terdapat keragaman hasil penurunan kedelai pada berbagai fase pertumbuhan, varietas dan tingkat cekaman kekeringan. Dogan dkk. (2007) menyatakan bahwa hasil kedelai menurun akibat cekaman kekeringan sebanyak 33\%, 31\% dan 50\% pada masingmasing fase R3, R5 dan R6. Cekaman kekeringan pada tingkat $50 \%$ air tersedia menurunkan kedelai varietas Detam-1 dan Malika sebanyak masing-masing $46 \%$ dan $51 \%$ (Taufiq \& Adie, 2013) dan Cikuray, Panderman, 
Burangrang, Tidar dan Wilis pada rentang hasil antara $41.7 \%$ - 62.6\% (Suhartina, 2007).

Informasi karakter morfologi dan fisiologi sangat diperlukan dalam program perakitan varietas kedelai tahan kekeringan. Indikator karakter morfologi tanaman merupakan salah satu metode seleksi genotipe tanaman secara tidak langsung yang relatif mudah dilakukan. Keragaman bobot biji berkontribusi sebesar 42\% pada karakter morfologi dan 48\% ditentukan karakter lain (Sumarno \& Zuraida, 2006). Identifikasi kekeringan pada tanaman kedelai dapat dilihat secara morfologi dan fisiologi, seperti pola perakaran, jumlah stomata, penyesuaian osmotik, fotosintat dan perubahan elastisitas dinding sel. Cekaman kekeringan sangat berpengaruh terhadap bobot kering tajuk, indeks luas daun, jumlah polong per tanaman, jumlah biji per tanaman dan hasil (Ku dkk., 2013). Uddin dkk. (2010) melaporkan bahwa kekurangan air meningkatkan nisbah akar terhadap tajuk sehingga dapat meningkatkan penggunaan air. Hal sejalan juga diungkapkan oleh Thu dkk., (2014) yang menyatakan bahwa perakaran akan terdistribusi pada area permukaan tanah (top soil) jika ketersediaan air tercukupi, namun jika dalam kondisi kekurangan air perakaran akan tumbuh dan berkembang pada tanah yang lebih dalam. Kemampuan tanaman untuk mempertahankan laju pertumbuhan pada kondisi cekaman kekeringan memungkinkan berkorelasi dengan kemampuan perakaran menyerap air sehingga mampu mengimbangi laju transpirasi (Taufiq \& Adie, 2013).

Tujuan penelitian ini adalah untuk mengevaluasi pertumbuhan dan hasil beberapa genotipe kedelai terhadap tiga tingkat kekeringan. Genotipe kedelai terseleksi dari ketiga cekaman akan digunakan untuk memberikan jastifikasi pemilihan dalam pemuliaan bibit unggul.

\section{METODE}

\section{Alat dan bahan}

Tanaman kedelai ditanam dalam pot plastik berukuran $35 \times 30 \mathrm{~cm}$ (bobot media tanam $7 \mathrm{~kg}$ ) tiga biji per pot. Pada 14 hari setelah tanam (HST) dilakukan penjarangan menjadi satu tanaman per pot. Pupuk organik dan pupuk anorganik setara $100 \mathrm{~kg}$ SP36/ha (0.21 g/pot), $50 \mathrm{~kg}$ urea/ha $(0.105 \mathrm{gr} / \mathrm{pot})$, dan $5 \mathrm{~kg} \mathrm{KCl} / \mathrm{ha}(0.105 \mathrm{~g} /$ pot) diaplikasikan pada saat tanam dengan cara dicampur rata dengan media tanam. Pemupukan urea dan $\mathrm{KCl}$ diaplikasikan dua kali yaitu pada 7 dan 35 HST. Perlakuan cekaman kekeringan dilakukan pada 14 HST dan pengamatan mulai dilakukan pada 21 HST.

\section{Metode yang digunakan}

Penentuan kapasitas lapang media berdasar pada pendekatan jumlah air yang mengisi pori-pori tanah (Veihmeyer \& Hendrickson, 1949 dalam Ghorbani dkk., 2017). Informasi jumlah air yang mengisi pori-pori 
tanah dapat diketahui melalui pengukuran kadar air dengan persamaan berikut:

$K A=\frac{B B-B K}{B K} \times 100 \%$

keterangan:

KA: Kadar air kapasitas lapang ditambahkan hingga mencapai kapasitas lapang

BB: berat basah tanah kapasitas lapang

BK: berat kering tanah oven

Berat basah (BB) tanah ditentukan dengan cara menyirami media tanam hingga keadaan jenuh yang ditandai dengan adanya air yang menetes dari media tanam. Permukaan media tanam diberi plastik untuk menghindari penguapan. Kemudian dibiarkan selama 48 jam. Setelah tidak ada lagi air yang menetes, tanah diambil sebanyak $100 \mathrm{~g}$ sebagai data BB. Pengambilan sampel secara komposit dan dilakukan sebanyak tiga kali ulangan.

Berat kering tanah (BK) ditentukan dengan cara mengeringkan media tanam BB selama 48 jam pada suhu $110^{\circ} \mathrm{C}$. Setelah media tanam dingin dengan cara memasukkannya dalam desikator, kemudian media tanam ditimbang sehingga diperoleh data BK.

Penambahan air disesuaikan dengan perlakuan. Untuk menjaga kondisi cekaman tetap berada pada perlakuan D1, D2, dan D3 maka pot setiap hari ditimbang. Volume air ditambahkan sesuai dengan berat yang hilang sampai dengan berat masing-masing perlakukan kembali seperti saat awal sebelum media ditanami.

\section{Tempat pelaksanaan}

Penelitian dilaksanakan di rumah kaca Balai Penelitian Tanaman Aneka Kacang dan Umbi pada November 2017 hingga Februari 2018.

\section{Rancangan percobaan}

Percobaan disusun dalam rancangan acak kelompok dua faktor dan diulang tiga kali. Uji cekaman dilakukan dengan beberapa faktor masing-masing adalah: 1) genotipe kedelai (G) yang terdiri dari G162 (G1), A6 (G2), Hitam-5 (G3), Detam-1 (G4) dan sebagai pembanding adalah varietas Dering-1 (G5), dan 2) dengan tiga tingkat cekaman kekeringan (D) yang terdiri dari; tanaman kedelai tumbuh pada kondisi 100\% kapasitas lapang (D1), tanaman kedelai tumbuh pada tingkat cekaman kekeringan $80 \%$ dari kapasitas lapang (D2), dan tanaman kedelai tumbuh pada tingkat cekaman kekeringan 60\% dari kapasitas lapang (D3). Terdapat 15 perlakuan dengan 3 kali ulangan, sehingga terdapat 45 satuan percobaan. Sampel yang digunakan dalam setiap perlakuan adalah 4 sampel.

\section{Analisa data}

Parameter yang diteliti adalah pertumbuhan (tinggi tanaman dan jumlah daun), pembungaan (umur berbunga, umur panen, jumlah bunga, jumlah polong isi dan jumlah polong hampa), hasil dan komponen hasil panen (bobot biji per tanaman dan berat kering brangkasan). Data dianalisis dengan menggunakan ANOVA, dilanjutkan dengan uji 
Tukey jika terdapat beda nyata dengan menggunakan perangkat lunak Minitab 17. Untuk mengetahui hubungan antar variable dan sejauh mana pengaruh variable bebas terhadap variable tidak bebas dilakukan uji regresi.

\section{HASIL DAN PEMBAHASAN}

\section{Komponen pertumbuhan}

\section{Tinggi tanaman}

Tingkat cekaman kekeringan berpengaruh nyata $(P<0.05)$ terhadap tinggi tanaman pada 21 hingga 49 hari setelah tanam (HST). Respon genotipe terhadap tinggi tanaman juga bervariasi secara signifikan $(P<0.001)$. Hal ini sejalan dengan hasil penelitian Taufiq \& Adie (2013) dan Dong dkk. (2019) yang menyatakan bahwa kekeringan mempengaruhi tinggi tanaman kedelai dan semua genotipe menjadi lebih pendek akibat penurunan tingkat ketersediaan air. Rata-rata tinggi tanaman genotipe pembanding (G5) tidak berbeda dengan genotipe $\mathrm{G} 1$, namun berbeda dengan genotipe lainnya (Gambar 1). Pertumbuhan tanaman terjadi sangat cepat pada 21 HST hingga 42 HST dan melambat pada 49 HST (Gambar 1). Hal ini menunjukkan genotipe yang diuji memiliki tipe pertumbuhan indeterminate.
Pada fase awal pertumbuhan (21 HST) tinggi tanaman pada ketiga tingkat cekaman kekeringan menunjukkan perbedaan yang nyata, demikian halnya juga terjadi peningkatan tinggi tanaman secara signifikan pada 28 hingga 49 HST. Tinggi tanaman pada kondisi kapasitas lapang (selanjutnya disebut perlakuan D1) meningkat $40.57 \%$ dari 21 HST ke 28 HST. Hal serupa juga terjadi pada kondisi tingkat kekeringan $80 \%$ dari kapasitas lapang (selanjutnya disebut perlakuan D2) dan pada kondisi tingkat kekeringan $60 \%$ dari kapasitas lapang (selanjutnya disebut perlakuan D3), tinggi tanaman meningkat $38.98 \%$ dan $33.46 \%$ secara berturut-turut. Namun, pada perlakuan D2 dan D3 persentase peningkatan tinggi tanaman menurun sejak 35 HST hingga 49 HST (Tabel 1). Terganggunya proses fisiologi tanaman, baik penyerapan air dan unsur hara serta fotosinstesis, mengakibatkan pertumbuhan tanaman terhambat yang dapat diindikasikan dengan peubah tinggi tanaman. Tanaman beradaptasi melalui mekanisme pertahanan dalam kondisi tercekam agar air, hara dan energi yang tersedia dalam jumlah terbatas dapat secara efisien dimanfaatkan untuk proses pertumbuhan (Wu dkk., 2014). 


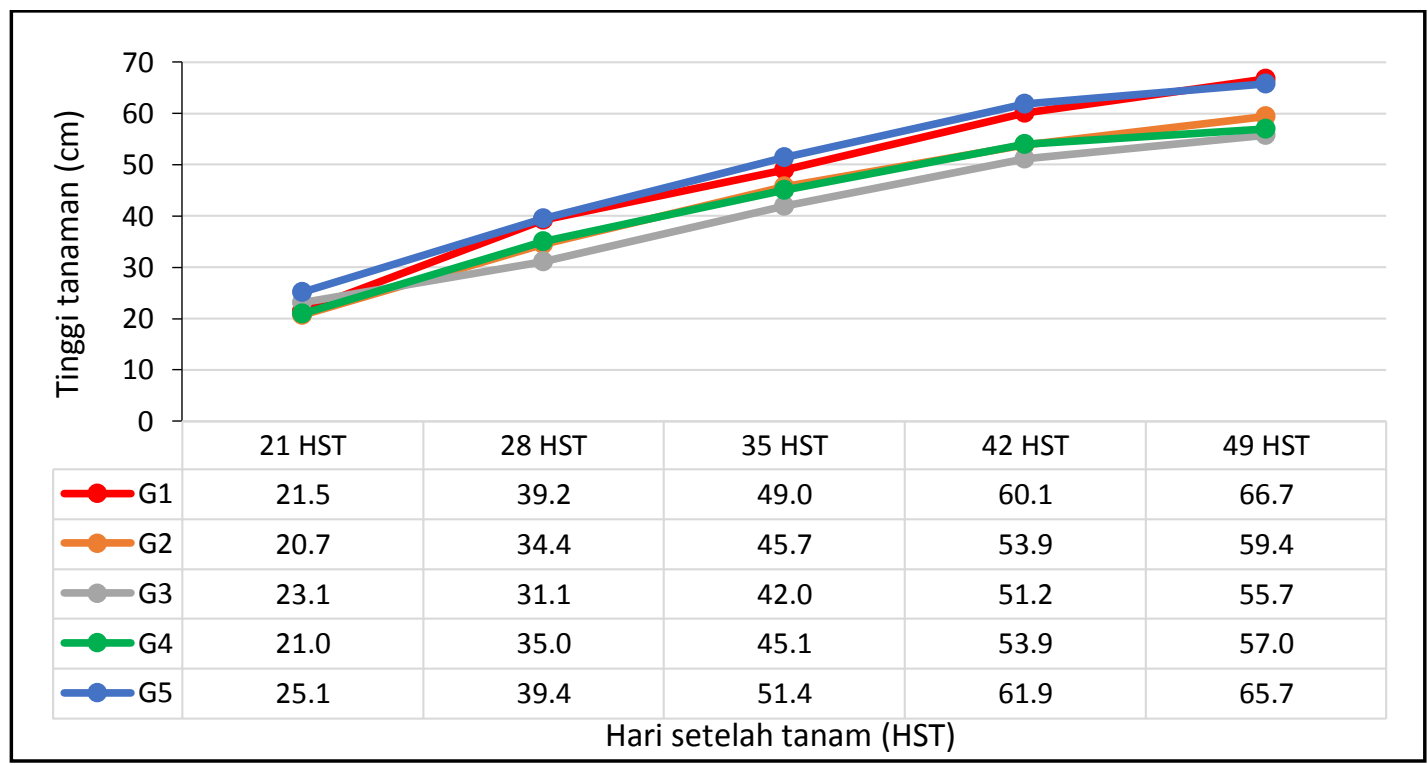

Gambar 1. Tinggi tanaman genotipe kedelai pada tiga tingkat kekeringan pada 21 hingga 49 hari setelah tanam (HST).

Tinggi tanaman secara signifikan berkorelasi positif dan dipengaruhi oleh jumlah buku subur $\left(\mathrm{R}^{2}=0.32 *\right)$. Hal tersebut mengindikasikan bahwa jika hingga pada fase reproduktif (49 HST) tinggi tanaman meningkat maka berpeluang menghasilkan bobot biji yang tinggi. Hasil penelitian tersebut sejalan dengan pernyataan Sumarno dan Zuraida (2006) bahwa genotipe kedelai memiliki daya hasil tinggi jika memiliki batang yang cukup tinggi dan jumlah polong per batang cukup banyak.

Tabel 1. Pengaruh tingkat cekaman kekeringan terhadap tinggi tanaman $(\mathrm{cm})$ dan jumlah daun genotipe kedelai

\begin{tabular}{cccccc}
\hline \multirow{2}{*}{$\begin{array}{c}\text { Tingkat cekaman } \\
\text { kekeringan (\%) }\end{array}$} & \multicolumn{5}{c}{ Umur tanaman (hari setelah tanam) } \\
\cline { 2 - 6 } & 21 HST & 28 HST & 35 HST & 42 HST & 49 HST \\
\hline \multicolumn{5}{c}{ Tinggi tanaman (cm) } \\
\hline D1 (100\%) & $23,23 \pm 1,3 \mathrm{a}$ & $39,09 \pm 3,2 \mathrm{a}$ & $51,04 \pm 3,4 \mathrm{a}$ & $60,08 \pm 2,7 \mathrm{a}$ & $65,07 \pm 3,9 \mathrm{a}$ \\
D2 (80\%) & $22,32 \pm 1,9 \mathrm{ab}$ & $36,58 \pm 4,8 \mathrm{a}$ & $47,35 \pm 4,8 \mathrm{a}$ & $57,73 \pm 4,6 \mathrm{a}$ & $62,52 \pm 4,6 \mathrm{a}$ \\
D3 (60\%) & $21,20 \pm 3,2 \mathrm{~b}$ & $31,86 \pm 6,7 \mathrm{~b}$ & $41,56 \pm 7,6 \mathrm{~b}$ & $50,84 \pm 9,2 \mathrm{~b}$ & $55,16 \pm 9,9 \mathrm{~b}$ \\
\hline \multicolumn{5}{c}{ Jumlah daun } \\
\hline D1 (100\%) & $4,87 \pm 0,2 \mathrm{a}$ & $6,80 \pm 0,4 \mathrm{a}$ & $9,50 \pm 0,5 \mathrm{a}$ & $9,28 \pm 0,7 \mathrm{a}$ & $9,05 \pm 0,9 \mathrm{a}$ \\
D2 (80\%) & $4,70 \pm 0,2 \mathrm{a}$ & $6,65 \pm 0,4 \mathrm{a}$ & $9,13 \pm 0,8 \mathrm{a}$ & $8,80 \pm 0,8 \mathrm{~b}$ & $8,47 \pm 0,9 \mathrm{~b}$ \\
D3 (60\%) & $4,60 \pm 0,2 \mathrm{a}$ & $6,10 \pm 0,4 \mathrm{~b}$ & $8,55 \pm 0,5 \mathrm{~b}$ & $8,21 \pm 0,6 \mathrm{c}$ & $7,87 \pm 0,8 \mathrm{c}$ \\
\hline
\end{tabular}

Keterangan: Angka sekolom yang diikuti oleh huruf yang sama tidak berbeda nyata pada uji Tukey $5 \%$

\section{Jumlah daun}

Tingkat cekaman kekeringan tidak kedelai menunjukkan perbedaan yang berpengaruh nyata terhadap jumlah daun pada signifikan terhadap jumlah daun. Interaksi 21 HST. Namun, cekaman kekeringan antara G x D juga berbeda nyata. Secara umum, berpengaruh nyata $(P<0.05)$ terhadap jumlah jumlah daun meningkat signifikan sejak 21 HST 
dan mencapai puncaknya pada 35 HST, namun jumlah daun menurun perlahan pada 42 HST hingga 49 HST (Gambar 2). Penurunan jumlah daun merupakan salah satu mekanisme tanaman dalam melakukan pertahanan diri terhadap cekaman kekeringan (Sacita dkk., 2018). Penurunan jumlah daun yang tinggi seiring dengan semakin lanjutnya pertumbuhan tanaman mengindikasikan laju daun senesen (menua) yang tinggi, sehingga menurunkan fotosintat (Sutoro dkk., 2008). Pada fase reproduktif jumlah daun senesen tanaman meningkat. Kekeringan berpengaruh terhadap percepatan laju daun senesen yang dapat memperpendek periode pengisian biji dan menghasilkan biji yang lebih kecil (Egli \& Bruening, 2004).

Terdapat korelasi positif yang lemah antara jumlah daun dan hasil biji $\left(R^{2}=0.24\right)$. Hal ini mengindikasikan bahwa semakin banyak jumlah daun yang dihasilkan pada kondisi cekaman kekeringan semakin tinggi bobot biji yang dihasilkan. Jumlah daun genotipe pembanding (G5) pada 21 hingga 49 HST lebih tinggi dibanding genotipe lainnya. Namun, genotipe G1 mampu mempertahankan rendahnya laju senesen yang diindikasikan dengan jumlah daun yang lebih tinggi hingga 49 HST dibanding genotipe lainnya (Gambar 2). Rendahnya laju senesen mengindikasikan peningkatan bobot biji karena proses pengisian biji menjadi lebih lama (Egli \& Bruening, 2004).

Secara umum jumlah daun menurun pada perlakuan tingkat cekaman kekeringan D2 dan D3 dibanding D1. Namun jumlah daun pada perlakuan D2 tidak berbeda nyata dengan perlakuan D1. Pada 28 HST persentase penurunan jumlah daun pada D3 lebih besar (10,3\%) dibanding D2 (2,2\%). Pada 35 hingga 49 HST secara berturut-turut persentase penurunan jumlah daun perlakuan D3 $(10,0 \%$, 11,5\% dan 13,0\%) lebih tinggi dibanding D2 (3,9\%, 5,2\% dan 6,4\%) (Tabel 1). Hal ini mengindikasikan bahwa cekaman kekeringan menurunkan jumlah daun tanaman kedelai.

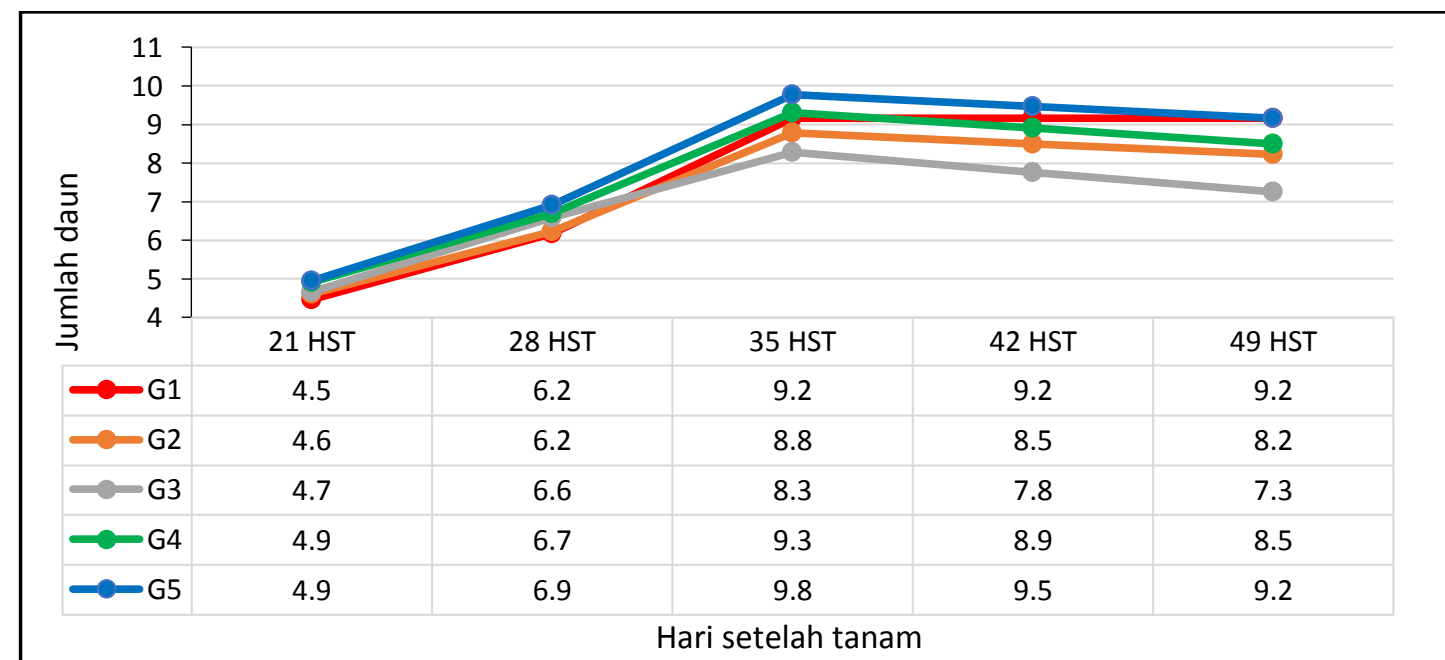

Gambar 2. Jumlah daun per tanaman genotipe kedelai pada tiga tingkat kekeringan pada 21 hingga 49 hari setelah tanam (HST) 


\section{Komponen pembungaan}

\section{Umur berbunga}

Umur berbunga genotipe kedelai dipengaruhi oleh tingkat cekaman kekeringan dan respon genotipe terhadap umur berbunga menunjukkan keragaman yang signifikan $(P<0.05)$. Interaksi antara keduanya ( $G \quad x \quad D)$ juga menunjukkan perbedaan yang nyata.

Tingkat cekaman kekeringan memperpendek umur berbunga menjadi 34 HST dan 33 HST pada perlakukan D2 dan D3 secara berturut- turut (Gambar 3). Genotipe G3 memiliki umur berbunga tercepat dibanding genotipe pembanding (G5) dan genotipe lainnya. Umur berbunga berkorelasi positif dengan bobot biji $\left(R^{2}=0.014\right)$. Walaupun nilai pengaruh tersebut lemah namun menunjukkan hubungan yang positif antara kedua peubah tersebut. Artinya, genotipe yang berbunga lebih cepat mempunyai periode generatif yang panjang, sehingga berpeluang menghasilkan biji yang lebih tinggi (Taufiq \& Adie, 2013).

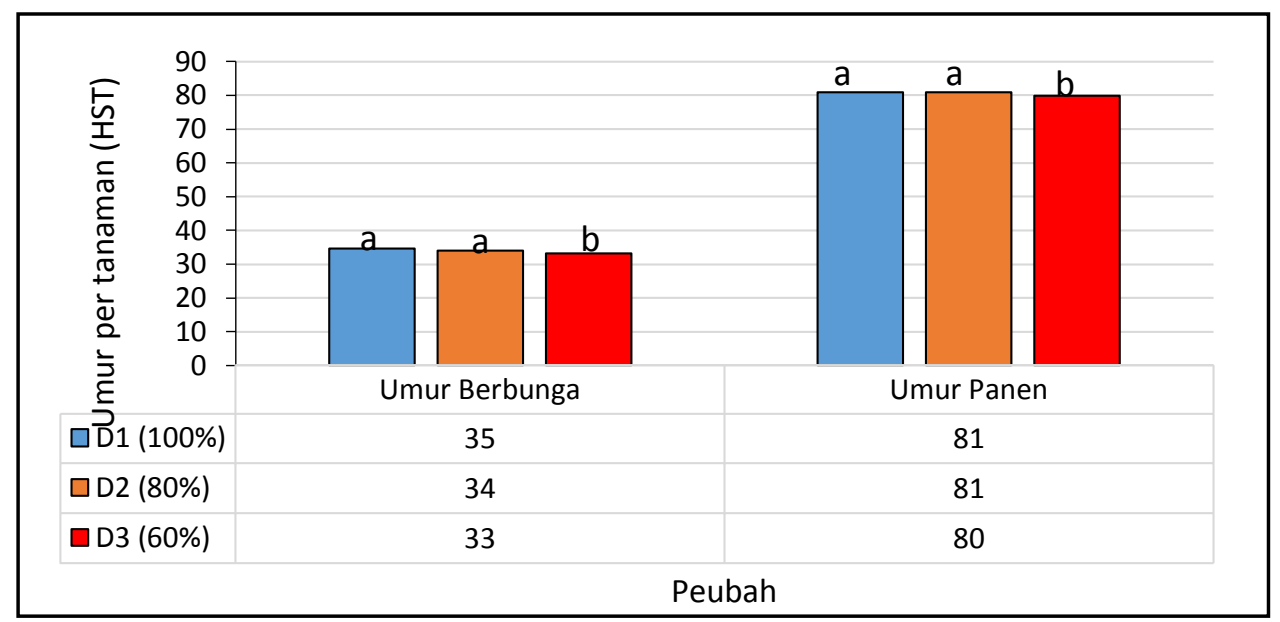

Gambar 3. Umur berbunga dan umur panen (HST) genotipe kedelai pada tiga tingkat cekaman kekeringan. Huruf yang sama pada diagram batang pada masing-masing peubah menunjukkan tidak berbeda nyata pada uji Tukey $5 \%$

\section{Jumlah bunga}

Cekaman kekeringan secara signifikan menurunkan jumlah bunga per tanaman $(P<0.05)$. Respon genotipe terhadap jumlah bunga juga bervariasi. Interaksi antara kedua perlakukan $\mathrm{G} x$ D menunjukkan perbedaan yang nyata $(P<0.05)$. Jumlah bunga per tanaman menurun sebesar $14.6 \%$ pada perlakuan D3, sedangkan persentase penurunan jumlah bunga pada perlakuan D2 lebih kecil (5.2\%) dibanding D3 (Gambar 4).

Rata-rata jumlah bunga terbanyak ada pada genotipe pembanding (G5) dan tidak berbeda nyata dengan genotipe lainnya. Namun, rata-rata jumlah bunga terendah adalah genotipe G3. Jumlah bunga berkorelasi positif dengan bobot biji $\left(R^{2}=0.154\right)$, artinya semakin banyak jumlah bunga semakin meningkatkan bobot biji atau hasil kedelai. Dalam hal ini, jumlah bunga genotipe $\mathrm{G} 1$ kedua tertinggi setelah genotipe pembanding (G5) dan lebih banyak dibanding G3 sehingga genotipe tersebut dapat diidentifikasi sebagai genotipe yang toleran kekeringan. 


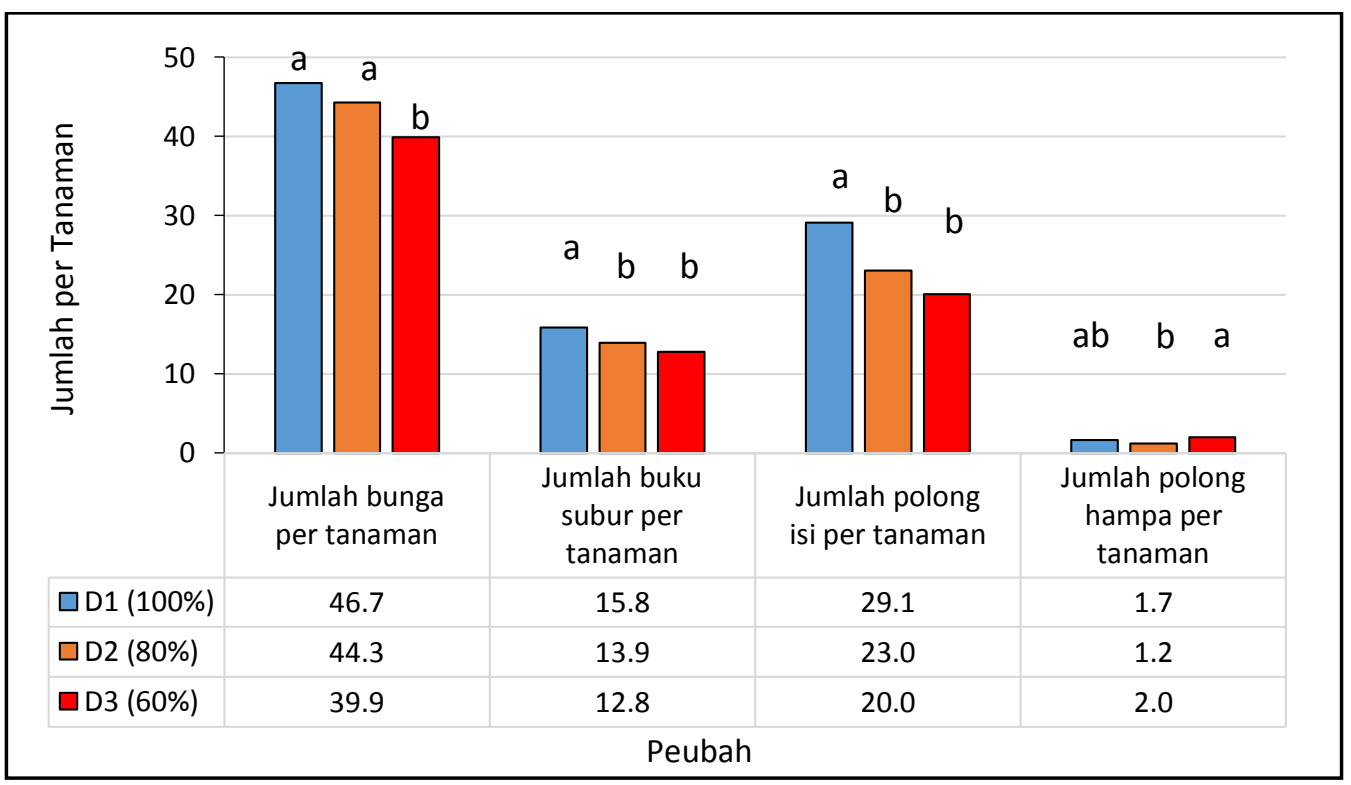

Gambar 4. Jumlah bunga, jumlah buku subur, jumlah polong isi dan jumlah polong hampa per tanaman genotipe kedelai pada tiga tingkat cekaman kekeringan. Huruf yang sama pada diagram batang pada masing-masing peubah menunjukkan tidak berbeda nyata pada uji Tukey $5 \%$

\section{Komponen hasil dan hasil}

Hasil analisis ragam menunjukkan bahwa kekeringan berpengaruh nyata $(P<0.001)$ terhadap hasil dan komponen hasil genotipe kedelai. Perbedaan genotipe juga berpengaruh nyata terhadap peubah umur panen, jumlah buku subur per tanaman, jumlah polong isi dan hampa, bobot kering brangkasan, bobot biji serta bobot 100 biji. Interaksi semua peubah hasil dan komponen hasil juga memperlihatkan perbedaan yang signifikan $(P<0.001)$. Hal ini menunjukkan bahwa genotipe yang diuji mempunyai respon yang berbeda terhadap tiga tingkat kekeringan.

\section{Umur panen}

Cekaman kekeringan berpengaruh nyata terhadap umur panen genotipe kedelai $(P<0.05)$. Respon genotipe terhadap umur panen juga menunjukkan keragaman. Interaksi antara $G \times D$ menunjukkan perbedaan yang nyata. Hal ini mengindikasikan bahwa cekaman kekeringan mempercepat proses pematangan tanaman. Pada perlakuan D2 umur panen genotipe kedelai tidak berbeda dengan perlakukan D1, namun perlakukan D3 mempercepat umur panen menjadi 80 HST (Gambar 3). Umur panen genotipe G3 lebih cepat dibanding genotipe pembanding (G5), sedangkan G2 dan G4 memiliki umur panen yang lebih lama.

Korelasi antara umur tanaman dengan bobot biji menunjukkan adanya hubungan positif yang lemah. Hal ini sejalan dengan hasil penelitian Sutoro dkk. (2008) menunjukkan bahwa total fotosintat yang dialokasikan ke dalam biji kedelai cenderung akan semakin banyak seiring dengan panjangnya umur panen tanaman. 


\section{Jumlah buku subur dan bobot kering} brangkasan

Cekaman kekeringan berpengaruh secara signifikan terhadap jumlah buku subur dan bobot kering brangkasan. Jumlah buku subur per tanaman menurun sebesar $12 \%$ pada perlakuaan D2 dan $19.3 \%$ pada perlakuan D3 (Gambar 4). Demikian halnya dengan peubah bobot kering brangkasan dipengaruhi oleh cekaman kekeringan secara signifikan. Hal ini sejalan dengan hasil penelitian Sacita dkk.
(2018) yang menyatakan bahwa cekaman kekeringan pada fase generatif dapat menurunkan bobot kering brangkasan secara signifikan. Bobot kering brangkasan per tanaman menurun sebesar $9.8 \%$ dan $16.6 \%$ pada perlakuan D2 dan D3 secara berturutturut (Gambar 5). Genotipe G5 memiliki bobot kering brangkasan tertinggi dibanding genotipe lainnya. Namun genotipe G1 menghasilkan bobot kering brangkasan kedua tertinggi setelah genotipe G5.

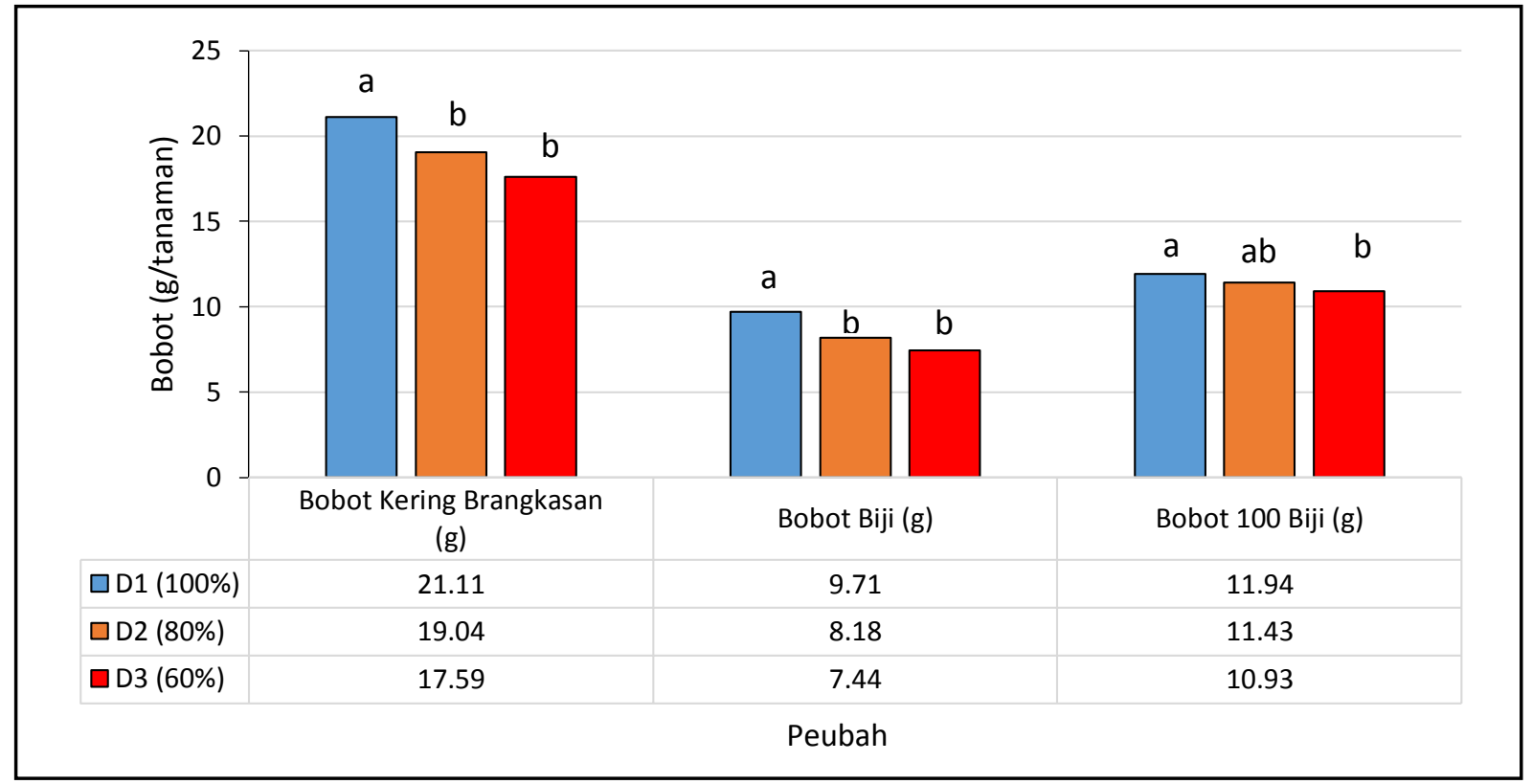

Gambar 5. Bobot kering brangkasan, bobot biji dan bobot 100 biji (g) genotipe kedelai pada tiga tingkat kekeringan. Huruf yang sama pada diagram batang pada masing-masing peubah menunjukkan tidak berbeda nyata pada uji Tukey $5 \%$

Bobot kering brangkasan secara signifikan jumlah polong yang banyak. Hal ini tercermin berkorelasi positif dengan jumlah polong isi pada genotipe $\mathrm{G1}$, dimana genotipe tersebut $\left(R^{2}=0.68^{* *}\right) \quad$ (Gambar 6). Genotipe dengan memiliki bobot kering brangkasan dan jumlah pertumbuhan yang baik, yang ditandai dengan polong lebih tinggi dan tidak berbeda nyata tingginya bobot kering brangkasan memiliki dengan genotipe pembanding (G5). 


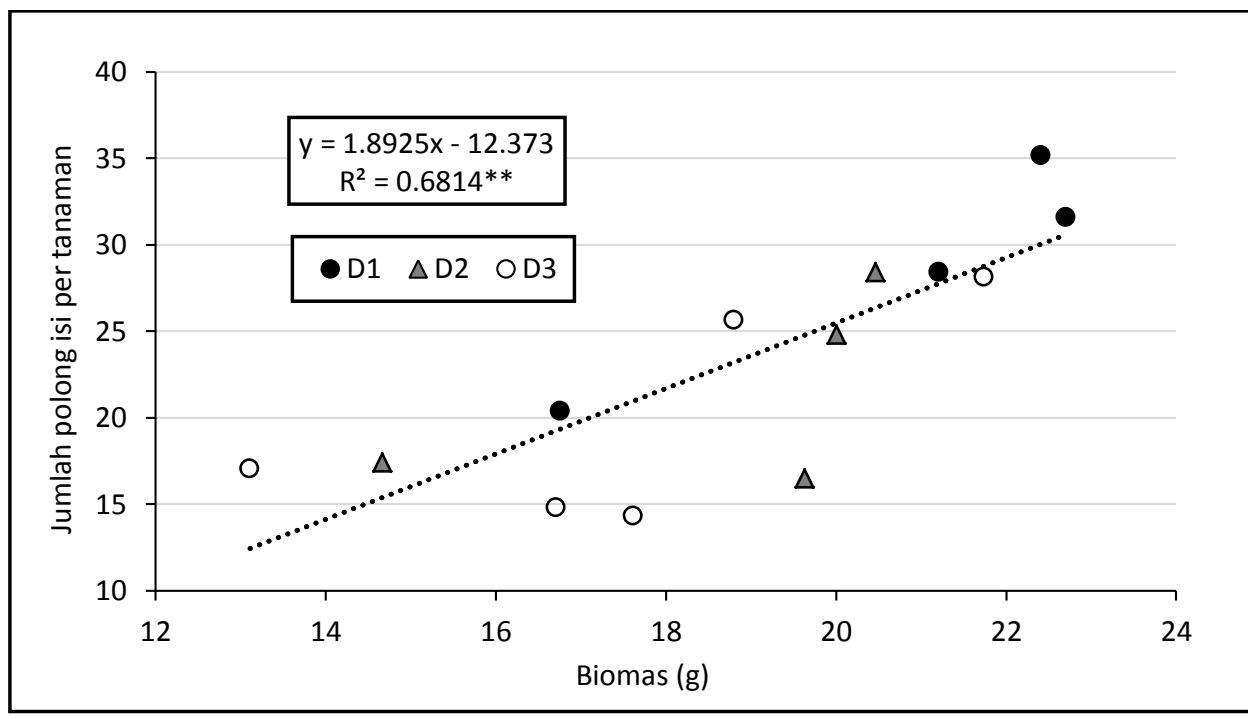

Gambar 6. Korelasi antara biomas dan jumlah polong isi per tanaman

\section{Jumlah polong}

Jumlah polong isi dan hampa per tanaman dipengaruhi oleh tingkat cekaman kekeringan dan genotipe kedelai $(P<0.05)$. Interaksi keduanya ( $\mathrm{D} \times \mathrm{G})$ juga menunjukkan perbedaan yang nyata $(P<0.05)$. Hal ini mengindikasikan bahwa respon genotipe terhadap jumlah polong isi dan hampa per tanaman berbeda dan cekaman kekeringan menurunkan jumlah polong isi dan meningkatkan jumlah polong hampa per tanaman. Penurunan persentase jumlah polong isi pada perlakuan D3 $(31.2 \%)$ lebih tinggi dibanding perlakukan D2 (20.8\%) (Gambar 4).

Jumlah polong hampa setiap tanaman meningkat pada kondisi cekaman kekeringan. Jumlah polong hampa meningkat pada perlakuan D3 dibanding perlakuan D1 dan D2. Semakin kecil ketersediaan air semakin banyak jumlah polong hampa. Hal ini sejalan dengan hasil penelitian Hatfield dkk. (2011) yang menyatakan bahwa pengisian polong merupakan fase yang sensitif terhadap keter- sediaan air. Sumarno \& Zuraida (2006) melaporkan bahwa daya hasil tinggi pada genotipe kedelai dapat dicirikan dengan tingginya batang dan banyaknya jumlah polong per batang.

Terdapat korelasi positif yang lemah antara jumlah polong isi dengan bobot biji $\left(R^{2}=0.06\right)$. Artinya, semakin banyak jumlah polong isi semakin tinggi hasil kedelai. Jumlah polong isi Genotipe pembanding (G5) tidak berbeda dengan genotipe $\mathrm{G} 1$, namun genotipe G3 memiliki jumlah polong yang paling rendah di antara genotipe yang diuji.

\section{Bobot biji (hasil) dan bobot 100 biji}

Penurunan ketersediaan air menurunkan hasil biji per tanaman rata-rata $9.71 \mathrm{~g} /$ tanaman menjadi 8.18 g/tanaman (15.7\%) pada perlakuan D2 dan $7.44 \mathrm{~g} / \operatorname{tanaman}(23.4 \%)$ pada perlakuan D3 (Gambar 5). Hasil penelitian ini sejalan dengan pernyataan Alqudah dkk. (2010) yang menyatakan bahwa cekaman kekeringan menghambat distribusi karbohidrat dari daun ke polong sehingga menurunkan bobot hasil. 
Bobot 100 biji secara nyata dipengaruhi oleh cekaman kekeringan. Pada perlakuan D3 persentase penurunan bobot biji menurun dua kali lipat, sebesar 8.5\% dibanding perlakuan D2 yaitu $4.2 \%$ (gambar 5). Hasil penelitian ini sesuai dengan pernyataan Dogan dkk. (2007) yang menyatakan bahwa kekeringan menyebabkan penurunan ukuran biji. Lenssen (2012) juga menyatakan bahwa penurunan bobot biji umumnya karena kehilangan berat total biji setiap polong dari seluruh tanaman. Lebih lanjut Manavalan dkk. (2009) menyimpulkan bahwa cekaman kekeringan selama fase pengisian biji mempengaruhi laju pertumbuhan biji melalui penurunan proses fotosintesis sehingga kebutuhan asimilasi untuk biji tidak terpenuhi.

Genotipe G1 memiliki bobot biji $(9.3$ $\mathrm{g} /$ tanaman) tertinggi dibanding genotipe lainnya. Pada peubah bobot 100 biji genotipe G3 paling tinggi $(16,5 \mathrm{~g} /$ tanaman) dibanding genotipe lainnya, namun genotipe G1 memiliki bobot 100 biji kedua tertinggi (10,9 g/tanaman) setelah G3 (tabel 2). Persentase penurunan bobot biji karena pengaruh kekeringan pada genotipe G1 lebih kecil (0.52 \%) dibanding genotipe pembanding G5 (10.26\%) dan genotipe G3 (4.10\%). Hal ini mengindikasikan bahwa genotipe G1 toleran terhadap kekeringan dibanding genotipe lainnya.

Pada awal pertumbuhan genotipe G1 memiliki performa yang sama dengan genotipe pembanding (G5), yaitu tinggi tanaman yang lebih tinggi dan jumlah daun yang lebih banyak dibanding genotipe lainnya. Berdasar pada korelasi tinggi tanaman dengan bobot biji/ hasil dan jumlah daun dengan hasil, mengindikasikan semakin tinggi tanaman maka berpotensi menghasilkan bobot biji yang lebih tinggi. Demikian pula semakin banyak jumlah daun maka peningkatan bobot biji semakin berpotensi (Egli \& Bruening, 2004; Sumarno \& Zuraida, 2006). Jumlah buku subur berkorelasi positif dengan tinggi tanaman. Tinggi tanaman dan jumlah buku subur genotipe G1 tidak berbeda dengan genotipe G5 namun lebih tinggi dibanding genotipe lainnya. Tinggi tanaman yang tinggi dan jumlah buku subur yang banyak akan menghasilkan bobot biji yang tinggi karena banyaknya hasil fotosintat yang didistribusikan pada biji (Alqudah dkk., 2010). Hal ini sejalan dengan karakter yang teridentifikasi pada genotipe $\mathrm{G} 1$, dimana genotipe tersebut memiliki tinggi tanaman dan jumlah buku subur yang lebih baik yang berasosiasi dengan bobot biji genotipe $\mathrm{G} 1$ yang lebih tinggi dibanding genotipe lainnya.

Pada fase reproduktif genotipe $\mathrm{G} 1$ memperlihatkan jumlah bunga dan jumlah polong isi yang tinggi. Genotipe toleran kekeringan dapat mempertahankan laju pertumbuhan pada awal fase reproduktif yang berasosiasi dengan tingginya bobot biji (Devi dkk., 2014). 
Tabel 2. Hasil (bobot biji dan bobot 100 biji) dan komponen hasil (biomas dan jumlah buku subur) lima genotipe kedelai

\begin{tabular}{|c|c|c|c|c|}
\hline \multirow{2}{*}{ Genotipe } & \multicolumn{2}{|c|}{ Hasil Biji (g/tanaman) } & \multirow{2}{*}{$\begin{array}{l}\text { Bobot Brangkasan Kering } \\
\text { (g/tanaman) }\end{array}$} & \multirow{2}{*}{$\begin{array}{c}\text { Jumlah Buku Subur } \\
\text { (per tanaman) }\end{array}$} \\
\hline & Bobot Biji & Bobot $100 \mathrm{Biji}$ & & \\
\hline G1 & $9.3 \pm 0.1 \mathrm{a}$ & $10.9 \pm 0.7 b$ & $20.1 \pm 1.2 \mathrm{a}$ & $15.4 \pm 0.9 \mathrm{a}$ \\
\hline G2 & $7.6 \pm 2.6 b$ & $9.1 \pm 1.5 \mathrm{c}$ & $20.0 \pm 2.6 \mathrm{a}$ & $13.6 \pm 3.9 a b$ \\
\hline G3 & $8.5 \pm 0.3 a b$ & $16.5 \pm 0.5 a$ & $14.8 \pm 1.8 b$ & $11.8 \pm 1.5 b$ \\
\hline G4 & $7.9 \pm 2.5 \mathrm{ab}$ & $10.2 \pm 1.9 \mathrm{bc}$ & $19.7 \pm 2.9 \mathrm{a}$ & $15.6 \pm 1.3 \mathrm{a}$ \\
\hline G5 & $8.9 \pm 0.6 \mathrm{ab}$ & $10.5 \pm 0.3 b c$ & $21.6 \pm 1.0 \mathrm{a}$ & $14.6 \pm 1.7 \mathrm{a}$ \\
\hline
\end{tabular}

Keterangan: Angka sekolom yang diikuti oleh huruf yang sama tidak berbeda nyata pada uji Tukey $5 \%$

\section{KESIMPULAN}

Cekaman kekeringan berpengaruh nyata terhadap tinggi tanaman, jumlah daun, umur berbunga, jumlah bunga, umur panen, jumlah buku subur, bobot kering brangkasan, jumlah polong, bobot biji dan bobot 100 biji. Respon genotipe berbeda secara signifikan pada setiap peubah yang diamati. Cekaman kekeringan menurunkan hasil genotipe kedelai sebesar $15.7 \%$ pada tingkat cekaman kekeringan $80 \%$ dari kapasitas lapang (D2), sedangkan penurunan hasil lebih besar $23.4 \%$ pada tingkat cekaman kekeringan 60\% dari kapasitas lapang (D3). Semakin rendah ketersediaan air semakin menurunkan produktivitas kedelai. Berdasar pada peubah tinggi tanaman, jumlah daun, jumlah bunga, bobot kering brangkasan, jumlah polong isi, bobot biji per tanaman dan penurunan bobot biji per tanaman karena cekaman kekeringan, genotipe G1 teridentifikasi sebagai genotipe yang toleran kekeringan.

\section{DAFTAR PUSTAKA}

Alqudah A.M., Samarah N.H., Mullen R.E. (2011). Drought Stress Effect on Crop
Pollination, Seed Set, Yield and Quality. In: Lichtfouse E. (eds) Alternative Farming Systems, Biotechnology, Drought Stress and Ecological Fertilisation. Sustainable Agriculture Reviews, vol 6. Springer, Dordrecht.

Balitbangtan. (2016). Deskripsi varietas unggul aneka kacang dan umbi. Jakarta: Badan Penelitian dan Pengembangan Pertanian.

Buezo, J., Sanz-Saez, Á., Moran, J. F., Soba, D., Aranjuelo, I., \& Esteban, R. (2019). Drought tolerance response of highyielding soybean varieties to mild drought: physiological and photochemical adjustments. Physiologia plantarum, 166(1), 88-104. https://doi.org/10.1111/ppl.12864

Daryanto, S., Wang, L., \& Jacinthe, P.-A. (2015). Global synthesis of drought effects on food legume production. PLOS ONE, 10(6), e0127401. https://doi.org/10.1371/journal.pone.012 7401

Devi, J. M., Sinclair, T. R., Chen, P., \& Carter, T. E. (2014). Evaluation of elite southern maturity soybean breeding lines for drought-tolerant traits. Agronomy Journal, 106(6), 1947-1954. https://doi.org/10.2134/agronj14.0242

Dogan, E., Kirnak, H., \& Copur, O. (2007). Deficit irrigations during soybean reproductive stages and CROPGRO-soybean simulations under semi-arid climatic conditions. Field Crops Research, 103(2), 154-159.

https://doi.org/10.1016/j.fcr.2007.05.009

Dong, S., Jiang, Y., Dong, Y., Wang, L., Wang, W., Ma, Z., ... \& Liu, L. (2019). A study on 
soybean responses to drought stress and rehydration. Saudi Journal of Biological Sciences, 26(8), 2006-2017. http://doi.org/10.1016/j.sjbs.2019.08.005

Egli, D. B., \& Bruening, W. P. (2004). Water stress, photosynthesis, seed sucrose levels and seed growth in soybean. The Journal of Agricultural Science, 142(1), 18.

http://doi.org/10.1017/S0021859604004 095

FAO. (2016). Climate change and food security: risks and responses. Food and Agriculture Organization of The United Nations.

Ghassemi-Golezani,K., Zafarani-Moattar, P., Raey, Y., \& Mohammadi, A. (2010). Response of pinto bean cultivars to water deficit at reproductive stages. Journal of Food, Agriculture \& Environment, 8(2), 801-804.

Ghorbani, M. A., Shamshirband, S., Hagli, D. Z., Azani, A., Bonakdari, H., \& Ebtehaj, I. (2017). Application of firefly algorithmbased support vector machines for prediction of field capacity and permanent wilting point. Soil \& Tillage Research, 172, 32-38. http://dx.doi.org/10.1016/j.still.2017.04. 009

Hatfield, J. L., Boote, K. J., Kimball, B. A., Ziska, L. H., Izaurralde, R. C., Ort, D., Thomson, A., M., Wolfe, D. (2011). Climate impacts on agriculture: Implications for crop production. Agronomy Journal, 103(2), 351-370. https://doi.org/10.2134/agronj2010.0303

Ku, Y. S., Au-Yeung, W. K., Yung, Y. L., Li, M. W., Wen, C. Q., Liu, X., \& Lam, H. M. (2013). Drought stress and tolerance in soybean. In: Board JE (ed). A Comprehensive Survey of International Soybean Research-Genetics, Physiology, Agronomy and Nitrogen Relationships. INTECH, New York.

Lenssen, A. (2012). Soybean response to drought. ICM News. Http://crops.extension.iastate.edu/cropn ews/2012/06/soybeanresponsedrought
Manavalan, L. P., Guttikonda, S. K., Phan Tran, L.-S., \& Nguyen, H. T. (2009). Physiological and Molecular Approaches to Improve Drought Resistance in Soybean. Plant and cell physiology, 50(7), 1260-1276. https://doi.org/10.1093/pcp/pcp082

Sacita. A. S., June. T, \& Impron. (2018). Soybean adaptation to water stress on vegetative and generative phases. Agrotech Journal, $3(2)$, http://dx.doi.org/10.31327/atj.v3i2.843

Suhartina. (2007). Evaluasi galur harapan kedelai hitam toleran kekeringan dan berdaya hasil tinggi. Paper presented at the Prosiding Seminar Peningkatan Produksi Kacang-kacangan dan Umbiumbian Mendukung Kemandirian Pangan, Bogor.

Sumarno, \& Zuraida, N. (2006). Hubungan korelatif dan kausatif antara komponen hasil dengan hasil kedelai. Jurnal Penelitian Pertanian Tanaman Pangan, 25(1), 38-44.

Sutoro, Dewi, N., \& Setyowati, M. (2008). Hubungan sifat morfofisiologis tanaman dengan hasil kedelai. Penelitian Pertanian Tanaman Pangan, 27(3), 185-190.

Taufiq, A., \& Adie, M. M. (2013). Pengaruh kekurangan air terhadap karakter agronomis dan fisiologis genotipe kedelai hitam. Jurnal Penelitian Pertanian Tanaman Pangan, 32(1), 25-35.

Thu, N. B. A., Nguyen, Q. T., Hoang., X. L. T., Thao., N. P., \& Tran., L. P. (2014). Evaluation of drought tolerance of the viatnamese soybean cultivars provides potential resources for soybean production and genetic engineering . BioMed Research International, 2014, 1-9. https://doi.org/10.1155/2014/809736

Uddin, S. U., Masateru, S., Kengo, I., \& Tawiah, A. J. (2010). The effect of deficit irrigation on root/shoot ratio, water use efficiency and yield efficiency of soybean. Journal of Rainwater Catchment Systems, 15(2), 3945. https://doi.org/10.7132/jrcsa.KJ00006069 061 
Wu, G., Zhou, Z., Chen, P., Tang, X., Shao, H., \& Wang., H. (2014). Comparative ecophysiological study of salt stress for wild and cultivated soybean species from the Yellow River Delta, China. Scientific World Journal, 1-13. https://doi.org/10.1155/2014/651745 